Review Article

\title{
The Innovation of Bachelor Geographical Pedagogical Curriculum: an Approach from Geography General Education, 2018
}

\author{
Ha Van Thang*, Pham Thi Binh \\ HCM City University of Education, 280 An Duong Vuong, Ward 4, District 5, Ho Chi Minh, Vietnam \\ Received 13 May 2021 \\ Revised 13 June 2021; Accepted 04 September 2021
}

\begin{abstract}
The purpose of this study is to point out the significant improvements of the Geography Education Curriculum 2018 compared to the 2006 ones in Vietnam. The research result is the analysis of Geography Education Curriculum improvements with scientific bases to explain them. To achieve this goal, theoretical research, practical experience summarization, consulting with experts to design geographic education programs are the main used methods. Research results contribute to the training and retraining of Geography teachers to meet the requirements of Vietnamese Geography Education innovation. Besides, it directs the improvement of training geography teacher-student curriculum.
\end{abstract}

Keywords: Innovation, bachelor curriculum, geography education curriculum.

\section{Introduction}

To meet the practical requirements, the General Education Curriculum of Vietnam has ${ }^{1}$ just been renewed and issued on December 28, 2018. Accordingly, the Geography Education Curriculum also changes in K-12 education.

It is a landmark and comprehensive improvement in all areas, including the development of education curriculum viewpoint, goals and content of Geography Education Curriculum, the orientation of education methods and assessment.

The key improvements compared to the 2006 Curriculum are: i) Schools Geography Education Curriculum 2018 is designed to orientate the development of learners'

\footnotetext{
* Corresponding author.

E-mail address: thanghv@hcmue.edu.vn

https://doi.org/10.25073/2588-1159/vnuer.4531
}

competencies and qualities, different from the 2006 Curriculum, a content-oriented ones. The geography competencies are well defined; ii) The contents of Geography are streamlined and updated to suit modern geography development; iii) The New Geography Curriculum focuses on experiential learning and assessment for the learner's progress as well as for the teachers' adjustment; and iv) One Geography Education Curriculum is applied in the whole country, but many textbooks are used; and the curriculum operation can be changed to suit the actual local conditions. This approach has not appeared in the current curriculum. The changes of the geography general education curriculum have a great impact on the geography teacher training program and foster the geography teachers at high schools to improve themselves. This article provides a complete, systematic and comprehensive picture of the improvements in 
the Geography Education Curriculum in Vietnam. Based on that, the author proposes solutions for training Geography teacher students at universities and retraining Geography teachers to meet the requirements of the New Geography Curriculum.

\section{Methodology}

In this paper, analyzed two types of data including secondary documents and quantitative data of a questionnaire survey on 5 universities.

We collected secondary data by applying the analyzing and synthesizing theoretical data methodology, comparing the 2006 and 2018 General Geography Education Curriculum. Materials are accessed from domestic and foreign databases in the fields of Geography Education, General Geography Education Curriculum versions, Geography Student-teachers training and Geography teacher training program. Specifically, we made an overview of foreign the Geography Education research to define core concepts including: Geography Education, Geography Education research, Geography Education Competencies and its' structure.

Primary data is gathered through a survey on 5 training institutions in the Southeast region and Mekong Delta. We classified, compared the objectives, output standards, content structure, innovation of training methods, and teaching plans. Besides, collection of data from training of geography pedagogical students and retraining high school geography teachers last five years, the project's Geography core Teacher Training Program (ETEP), the opinions of experts on geography education and teacher training curriculum, etc. are considered.

\section{Results and Disscuss}

\subsection{Renovation of Vietnam General Education Curriculum 2018}

2018 General Education Curriculum will replace the previous ones applied from 2006.
The current General Education Curriculum has completed its mission with remarkable educational achievements. However, it is necessary to be replaced with a more modern education curriculum to catch up with world development, especially, to supply the quality of human resources requirements. Besides, the developing trend of education curriculum and textbooks changes very quickly in the world; There are many new educational achievements that need to be promptly added to the national education curriculum. In the early $21^{\text {st }}$ century, the changes in education have moved from emphasizing educational content to the development of learners' competencies Curriculum. The designing approach of the 2018 General Education and the Geography Education Curriculum is completely different from 2006 ones, as we can see in Figure 1 [1].
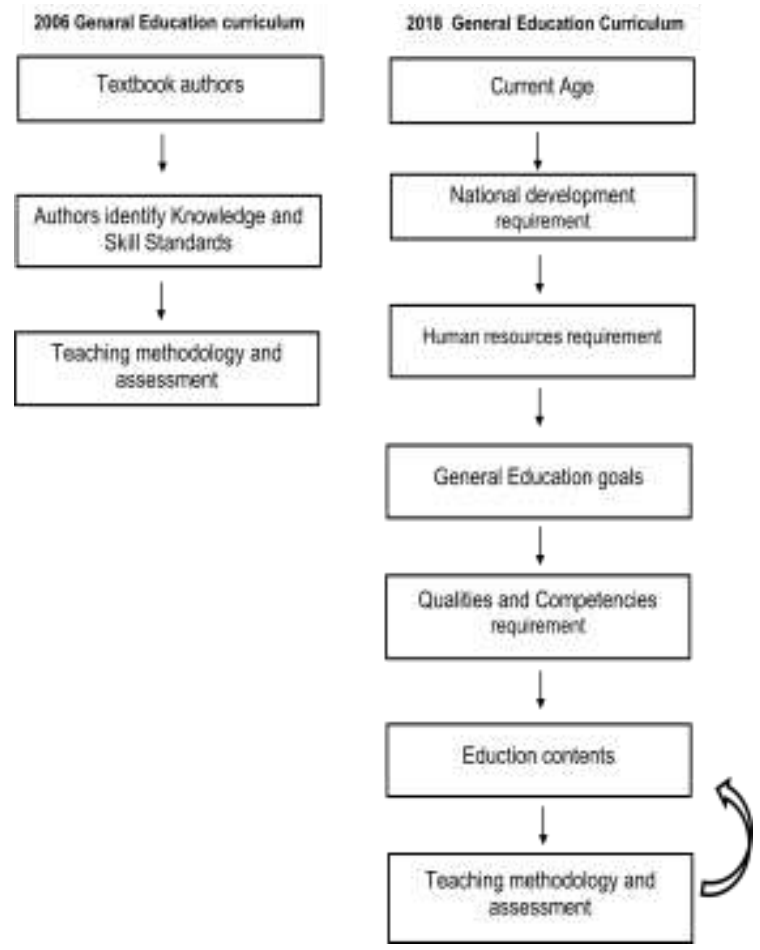

Figure 1. Designing approach of 2006 and 2018 General Education Curriculum [1].

There are 5 core qualities and 10 key competencies to develop for students in the General Education Curriculum 20180 (Figure 2). 


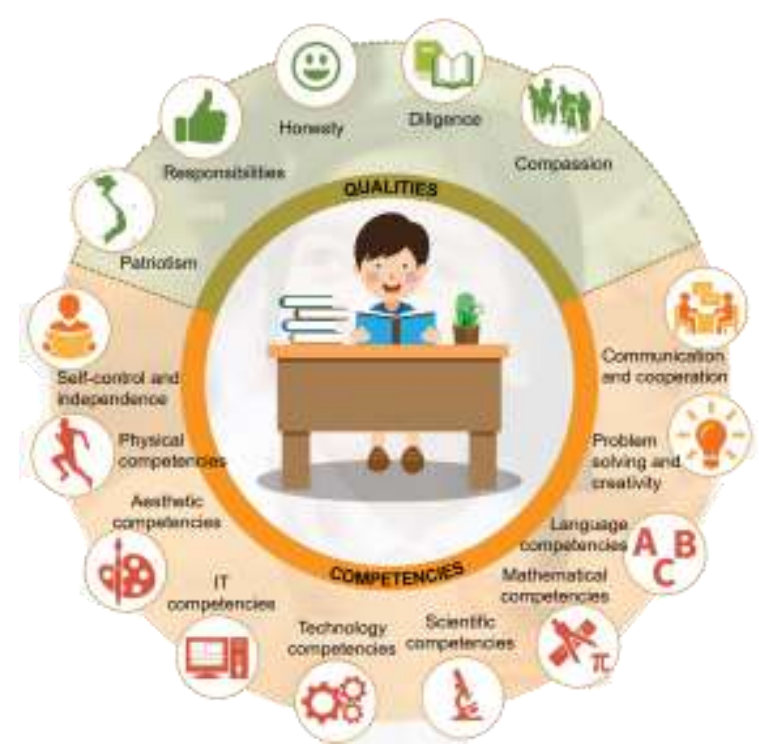

Figure 2. The 5 qualities and 10 competencies in the General Education Curriculum 2018 [2].

Changing approaches in designing the education curriculum will govern and adjust all stages of the education process. It aims to create a fundamental change in the quality of all subjects and education activities.

\subsection{General Geography Education Curriculum 2018}

Geography is a compulsory subject from grade 4 to 12 in Vietnam's General Education Curriculum 2006 and 2018. The outstanding improvements in the 2018 curriculum are indicated in the below table:

Table 1. Outstanding improvements in Geography Education Curriculum 2018 compared to $2006[4,6]$

\begin{tabular}{|l|l|}
\hline $\begin{array}{l}\text { Geography Education } \\
\text { Curriculum 2006 }\end{array}$ & $\begin{array}{l}\text { Geography Education } \\
\text { Curriculum 2018 }\end{array}$ \\
\hline Content-oriented design & $\begin{array}{l}\text { Competencies } \\
\text { oriented design }\end{array}$ \\
\hline Geography teaching & Geography Education \\
\hline $\begin{array}{l}\text { Unclear integration } \\
\text { and career orientation }\end{array}$ & $\begin{array}{l}\text { Deep integration } \\
\text { from low to high levels }\end{array}$ \\
\hline $\begin{array}{l}\text { A unique set } \\
\text { of textbooks }\end{array}$ & Many sets of textbooks \\
\hline
\end{tabular}

Firstly, The transforming concept from teaching Geography to Geography Education. When we search for the keyword "Geography teaching and learning" in Vietnamese, the results are extremely rich, but the keyword "Geography Education" is so rare. Commonly, the geography educators thought that School Geography is a field of teaching and learning. The concept of Geography Education was used in the 2018 Curriculum to give a broader concept of Geography teaching as well as an approach to the conception of countries around the world and the International Charter on Geography Education. In this study, the author uses Geography Education as the concepts of Sarah Bednarz and Rod Gerber.

Rod Gerber stated that "The way people learned different geography approaches, developed the skills to conduct geographical investigations, embraced the values associated with these approaches, and practiced them in their lives became known as geographical education. "Geography in the school curriculum involves the education of young people about, in and for the environment and society in which they live". Geography becomes the medium for education. It contributes to education through: i) Knowledge with understandings about people and environments on the whole world; ii) Fieldwork enabling learning in the community and local environment, and; iii) Learning for the society and environments that the people live in According to Sarah Bednarz (2010), the concept of geography education is the overlap and intersection part of geography and education.

So that, geography education research is where research in geography and in education overlap (Figure 3). Imagine geography and education as rotating overlapping discs, the overlap may occur where the research topics that both academic areas pursue. If the overlap occurs between learning theory and geography, research will address fundamental questions such as, "What is geographic learning? What is the nature of geographic knowledge? What skills enhance geographic learning?" If the overlap occurs between learning theory and one of the systematic specialties of geography, research will focus more narrowly on questions such as, "How do high school students learn to 
think about human-environment relationships?" (Gerber, 1996). If geography intersects with education's teacher preparation domain, research may explore how teachers gain specific kinds of subject knowledge [2].

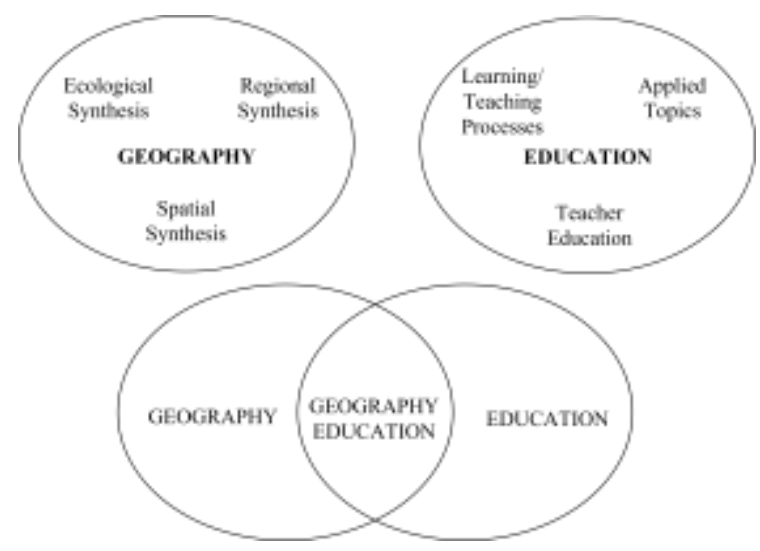

Figure 3. Geography Education defined as the overlap between Geography and Education [2].

To summarize, Geography Education is a way in which Geography educators guide learners to understand different Geography approaches, develop geographic discovery skills, embrace interrelated values and regarding these methods and practice them in their lives. Secondly, Geography Education Curriculum 2018 help to develop learners' competencies. The geography Education Curriculum 2006 is content - based. The target is to acquire knowledge, skills, and attitude. These was defined in the Knowledge and Skills Standards and the textbooks. In contrast, Geography Education Curriculum 2018 aims at developing the learners' competencies. This is presented in viewpoint, objectives, requirements and content, educational methods, and evaluation of the curriculum. In detail, "Geography Education Curriculum clearly identifies the qualities and competencies that can be formed and developed by this subject" [3]. "Geography Education Curriculum supports students form and develop Geography competencies - an expression of scientific competencies. At the same time, it develops students' major qualities and general competencies in accordance with other academic subjects and Education activities" [3]
"Geography subject contributes to the formation and development for students' major qualities and general competencies at levels appropriate and the subject in the General Education Curriculum" [3]. Geography competencies in Geography Education Curriculum include: Knowledge of Geography (Perception of the world in spatial perspective, Explanation of geographical phenomena and processes (natural, socio-economic)); Inquiring Geography (Use of geographical tools, Field studies, Use of the Internet in Geography study); Applying Geography knowledge and skills learned (Updating information, relating to the life, Fulfilling projects to explore the locality, Applying Geography knowledge to solve practical problems) [3] (Figure 4).

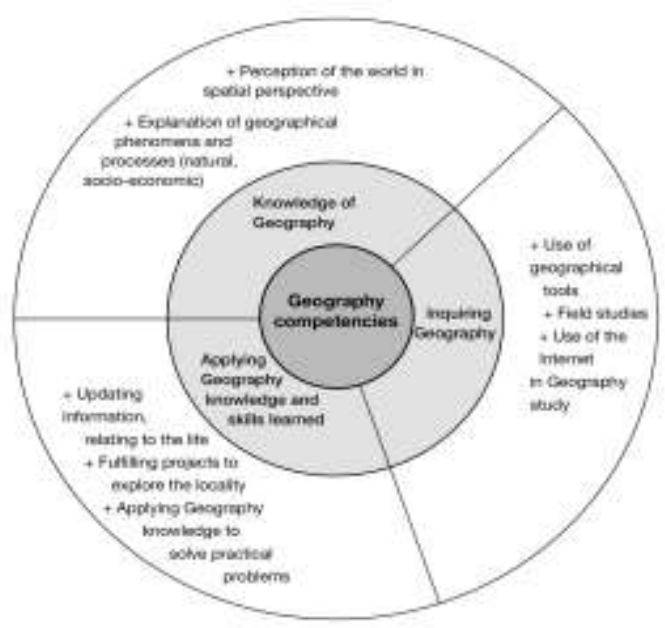

Figure 4. Geography competencies for students in Geography Education 2018 [3].

What is the basis for establishing a specific Geography competency framework? N. V. Thinh is one of the authors of the Geography Education Curriculum, in the study "Identifying specific Geography competencies and assess students' ability to achieve in new Education Curriculum" (2019) explained this. The authors based on the study of the Geography Curriculum of England, the National Geography Standard of the United States, the Geography Education of Germany, and inheriting the 2006 Vietnamese Geography Education Curriculum to determine: 
- Geography Competencies are specific competencies of Geography, which are also the foundation for Geography Education in schools.

- Geography Standards (requirements) are determined for each level of education. It is based on the students' identified competencies and the development of knowledge, skills, the psychology of students [4].

Thirdly, Geography Education content is improved based on the integrated, practical, and modern orientation. The concept of designing Geography Educational Content Direction is deeply integrated at lower education levels (at primary) and gradually highly divided at higher levels (secondary and then high school). In specific, at the primary school, History and Geography subject is taught in grades 4 and 5 . Geography and History contents are integrated into local, national, regional and the world topics. At secondary school, History and Geography is also one subject but separated into 2 independent parts of contents. Integration education takes place in some joined topics from grade 7 to 9, for example, "The Geography Discoveries", in grade 7. Geography is an independent subject at high school curriculum and becomes an optional subject. The designing purpose is to ensure adequate provision of basic Geography knowledge and skills for students on the basis of the Education Stage. Besides, it guides the career orientation related to Geography at high school.

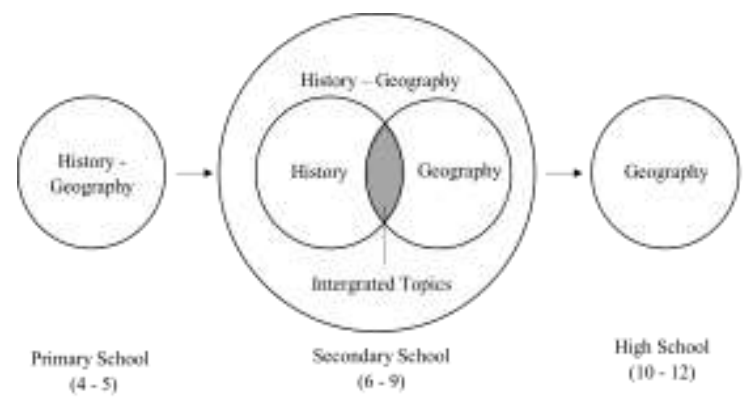

Figure 5. Deep integrationat lower and gradual differentiation at higher education levels (by Authors).
The 2006 Geography Education Curriculum does not clearly indicate to integration education. Geography is not an integrated subject from primary to high school. It is a compulsory subject at three education levels. While, in the 2018 curriculum, geography is an integrated subject with segmented methodology.

The 2006 and 2018 Geography Education Curriculum are "Spiral model" (Figure 6). However, the detail structure the 2018 is different for the aim to development the geography competences line. It ensures the system - structure of Geography when Geography knowledge and skills are developed from basic to advance in a stable structure. The learners must follow all 3 Education levels to complete General Geography knowledge whereas the 2018 Curriculum stops at secondary school. As a result, career orientation is limited, and Geography Education Curriculum becomes unnecessarily cumbersome. Moreover, this model is not compatible with normative development because Geography is researched separately.

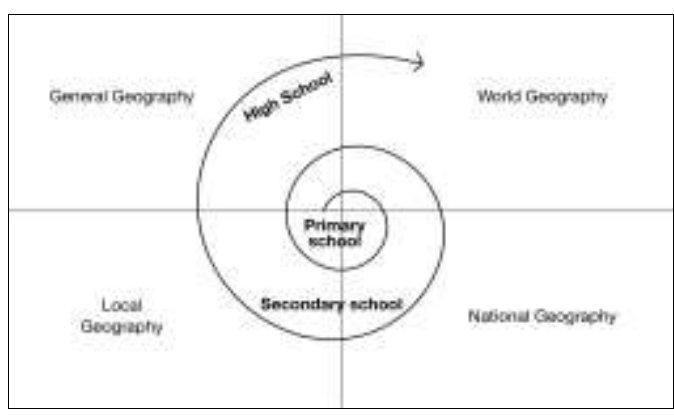

Figure 6. "Spiral model" in 2006 Geography Education Design (by authors).

Geography Educational Content has not changed too much comparing to the 2006 curriculum. However, it has been improved, updated, and redesigned accordingly. The curriculum ensures the systematic - structural and characteristics of Geography. Content options and implementations clearly show the structure of Geography, from general geography to world, national and local geography. However, it is not done in a linear manner, according to the normative development of Geography and students' perceptions. 
Students start with Geography through the lessons of local Geography where they are living, then the regional geography, the national geography and finally the world geography. This approach makes Geography knowledge more accessible to elementary students. Moreover, it also emphasizes the students own experience. At secondary school, Geography starts systematically, from general Geography, regional and national Geography. This content structure is reproduced, not repeated but more advanced for career orientation at high school. Thus, the implementation is still "spiral model" with different content structure and focusing on competences line development (Table 2, Figure 7).

Table 2. The 2018 Geography Education content structure from primary to high school [5]

\begin{tabular}{|l|l|l|}
\hline $\begin{array}{l}\text { Geography } \\
\text { Education contents }\end{array}$ & Basic & Advanced \\
\hline $\begin{array}{l}\text { General Geography } \\
\text { - Map; Physical } \\
\text { Geography; }\end{array}$ & $\begin{array}{l}\text { - Grade 2,3 } \\
\text { (integrated } \\
\text { into Nature } \\
\text { and Society } \\
\text { Socio-economic } \\
\text { Geography }\end{array}$ & - Grade 10 \\
\hline $\begin{array}{l}\text { World Geography } \\
\text { - Continents: nature } \\
\text { and people; Issues of } \\
\text { the world and }\end{array}$ & - Grade 4 & \\
regions & - Grade 7 & - Grade 11 \\
\hline $\begin{array}{l}\text { Nation Geography } \\
\text { - Physical Geography } \\
\text { - Socio-economic } \\
\text { Geography; } \\
\text { Geography division } \\
\text { of territories }\end{array}$ & - Grade 4,5 & - Grade 12 \\
\hline $\begin{array}{l}\text { Local Geography } \\
\text { - Nature, People } \\
\text { Culture,... where } \\
\text { students live }\end{array}$ & - Grade 8,9 & \\
\hline
\end{tabular}

Integrated topics at secondary school connects Geography and History knowledge. The purpose is to help students applying both Geography and History knowledge and skills to solve complex learning and practical problems. Therefore, it helps forming integrated thought and problem-solving competencies for students. These topics are highly integrated when solving learning content that require learners to apply the combined knowledge of many fields rather than Geography individually.

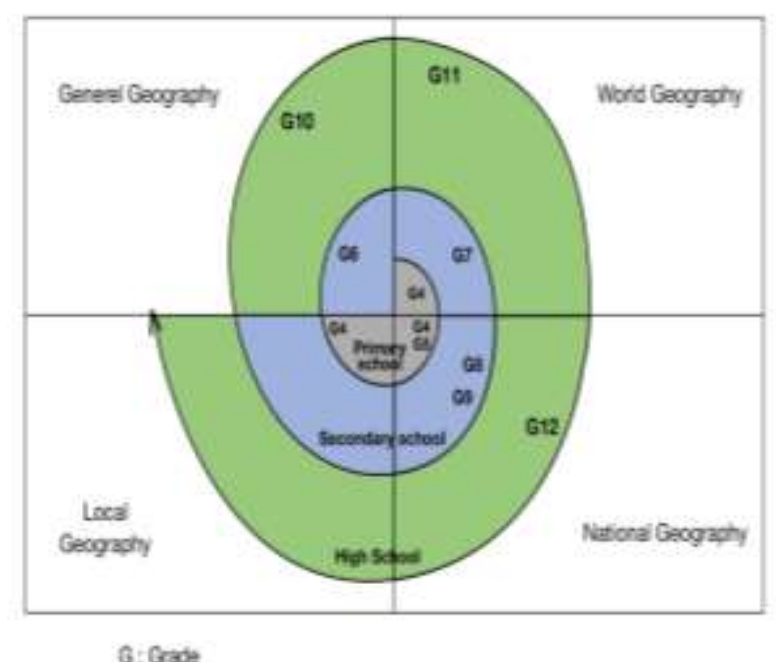

Figure 7. "Spiral model" in 2018 Geography Education Design (by authors).

Fourthly, one curriculum with many sets of Geography textbooks. There was only one Geography textbook available to students in the whole country and educating Geography operates around that (Table 3).

It creates many disadvantages such as non-local features, lack of diversity, stereotypes. Therefore, the General Education Curriculum 2018 and Geography Education Curriculum only provide the content frame and requirements. Publishers, Education Universities, and Education departments will participate in the compilation of various Vietnamese Ministry of Education and Training provides textbook orientation with the strict requirements [6]. 
Table 3. Geography Education contents in the Geography Education Curriculum 2018 (from grade 4 to 12) [3]

\begin{tabular}{|c|c|c|c|c|c|c|c|c|c|}
\hline \multirow{2}{*}{ Geography contents/Integrated topics } & \multicolumn{2}{|c|}{ Primary School } & \multicolumn{4}{|c|}{ Secondary School } & \multicolumn{3}{|c|}{ High School } \\
\hline & 4 & 5 & 6 & 7 & 8 & 9 & 10 & 11 & 12 \\
\hline Geography Learning facilities & $\mathrm{x}$ & & & & & & & & \\
\hline Students' local Geography & $\mathrm{x}$ & & & & & & & & \\
\hline The North Mountain region of Vietnam & $\mathrm{x}$ & & & & & & & & \\
\hline The Central Coast region of Vietnam & $\mathrm{x}$ & & & & & & & & \\
\hline The Highlands region of Vietnam & $\mathrm{x}$ & & & & & & & & \\
\hline The South region of Vietnam & $\mathrm{x}$ & & & & & & & & \\
\hline Vietnam country and people & & $\mathrm{x}$ & & & & & & & \\
\hline $\begin{array}{l}\text { The first countries on the territory } \\
\text { of Vietnam }\end{array}$ & & $\mathrm{x}$ & & & & & & & \\
\hline Building and defending our country & & $\mathrm{x}$ & & & & & & & \\
\hline The Neighboring countries & & $\mathrm{x}$ & & & & & & & \\
\hline Exploring the world & & $\mathrm{x}$ & & & & & & & \\
\hline Building our world & & $\mathrm{x}$ & & & & & & & \\
\hline Why study Geography & & & $\mathrm{x}$ & & & & & & \\
\hline Map & & & $\mathrm{x}$ & & & & & & \\
\hline The Earth & & & $\mathrm{x}$ & & & & & & \\
\hline Climate and climate change & & & $\mathrm{x}$ & & & & & & \\
\hline Water on the Earth & & & $\mathrm{x}$ & & & & & & \\
\hline Soil and creature on the Earth & & & $\mathrm{x}$ & & & & & & \\
\hline People and nature & & & $\mathrm{x}$ & & & & & & \\
\hline $\begin{array}{l}\text { Continents: Europe; Asia; Africa; } \\
\text { Americas; Australia, Antarctica }\end{array}$ & & & & $\mathrm{x}$ & & & & & \\
\hline $\begin{array}{l}\text { Vietnam: Location and territory; } \\
\text { Topography and minerals }\end{array}$ & & & & & $\mathrm{x}$ & & & & \\
\hline $\begin{array}{l}\text { Vietnam: climate and rivers; Creatures } \\
\text { and soil; Sea, island, and archipelago }\end{array}$ & & & & & $\mathrm{x}$ & & & & \\
\hline Vietnam: People & & & & & & $\mathrm{x}$ & & & \\
\hline Vietnam: Economic sectors Geography & & & & & & $\mathrm{x}$ & & & \\
\hline Vietnam: Geography division & & & & & & $\mathrm{x}$ & & & \\
\hline $\begin{array}{l}\text { Physical Geography: Earth, lithosphere, } \\
\text { Atmosphere, Hydrography, Biosphere }\end{array}$ & & & & & & & $\mathrm{x}$ & & \\
\hline $\begin{array}{l}\text { Socio-Economic Geography: People, } \\
\text { economic development resources, } \\
\text { Economic Sectors Geography, Sustainable } \\
\text { Development, and Green Growth }\end{array}$ & & & & & & & $\mathrm{x}$ & & \\
\hline $\begin{array}{l}\text { Integrated Topics: Climate change, } \\
\text { Urbanization, Writing Geography reports }\end{array}$ & & & & & & & $\mathrm{x}$ & & \\
\hline
\end{tabular}




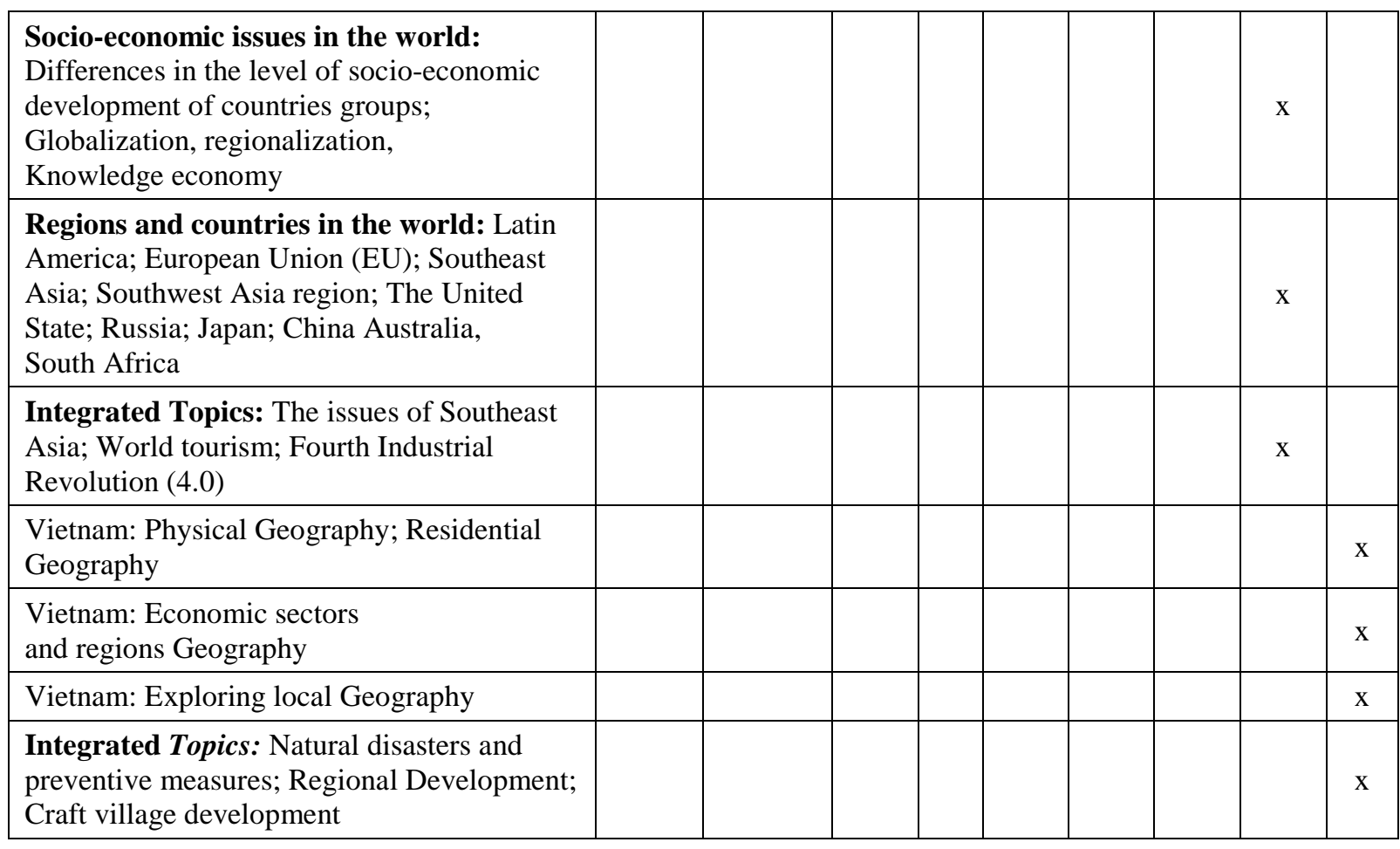

\subsection{Training and Enhancing Geography Teachers}

\subsubsection{Geography Education Competencies}

Geography teachers are currently implementing the 2006 Geography Education Curriculum. Changing Curriculum is required training courses for the high school teacher. In addition, training curriculum for Geography student-teachers in the Education universities also needs improvements to catch up and support General Education curriculum renovation.

Compatibility between Geography Education Curriculum, Training Geography student-teachers Curriculum and Retraining Geography teacher are necessary (Figure 8). Geography Education Curriculum develops students with specific Geography capabilities. Respectively, both training and retraining the Geography teacher curriculum must follow the Teaching Profession's Competencies, and Geography teacher is Geography Education competencies.

"Geography Education Competency is defined as the ability to identify and implement specific strategies, processes and measures to formulate and develop Geography Competencies for their students on the basis of subject curriculum requirements, learners' cognitive characteristics and behavior and diverse learning situations" [7].

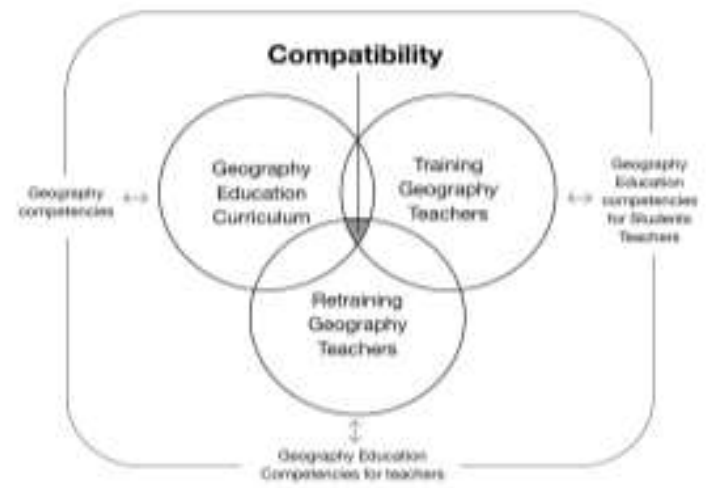

Figure 8. The relationship between developing Geography competencies and training and re-training Geography teachers (by authors).

Geography Education Competency is composed of components including Geography-specific competency, Applying education knowledge into Geography Education in high school and Supportive Competency. The components are divided into those elements where the specific expression competencies and Geography 
Competency is the main basis. Geography Education Competency is a "dynamic system" because it is always influenced by external factors such as socio-economic development, technological revolution, the renovation of the General Education Curriculum. That means Geography teachers must improve their competency to meet the changes of requirements in reality (Figure 9) [7].

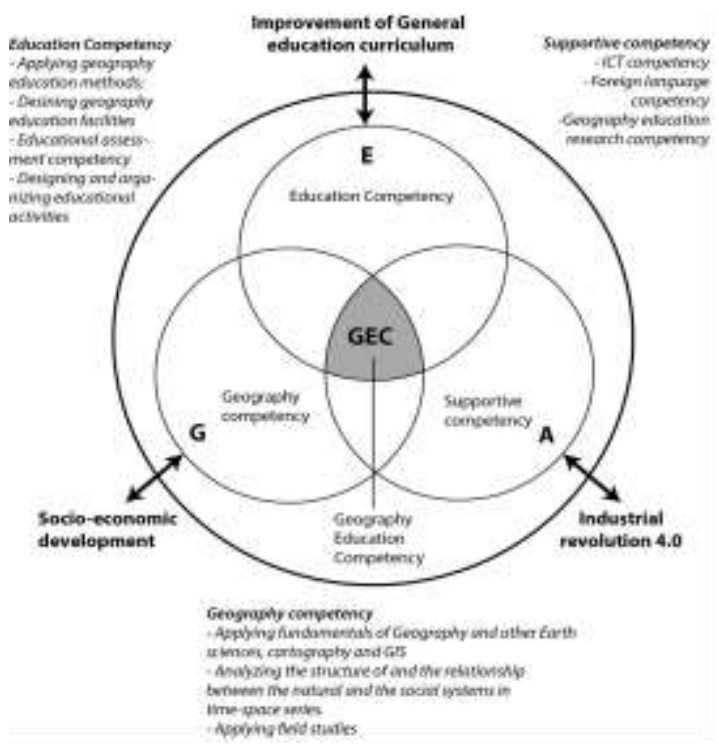

Figure 9. Structure of the Geography Education Competency [7].

3.3.2. Training Geography Student-teachers Curriculum in Education Institutions

Currently, Vietnam has 16 Training Geography teacher institutions in 3 main types of schools: Geography Departments of Education Universities, Geography Departments in Education Universities belong to General Universities and Geography subjects in the Education Departments of General University (Figure 10). The training curriculum is designed and improved under the guidance of the Vietnam Ministry of Education and Training on the output standards of the pedagogical schools. However, it is different from the universities. The following common different points are:

i) Training curriculums are designed by the credit system, approximately 140 credits;

ii) Training curriculum determines the output standards on qualities and competencies, including: Qualities, General competencies, professional Geography Competencies, professional teacher competencies;

iii) Training curriculums are divided into 3 groups of knowledge - skills: General Knowledge and skills; Geography knowledge and skills; Teacher special knowledge and skills;

iv) Training curriculums have increased the volume of modules and group of teaching methodology and professional teaching practice;

v) Training content is changed and updated to meet renewed Geography Education Curriculum;

vi) These programs are accredited according to the standards of AUN-QA (ASEAN University Network - Quality Assurance) and MOET (Vietnamese Ministry of Education and Training).

In this paper, we presents an analysis of the curriculum of 5 institutions in the Southeast and the Mekong including training objectives, content and plans for clarifying the above statements [8] Research places and sample distribution are presented in Figure 10.

Regarding the output goals and standards, all the curriculums pursue the following objectives: i) Bachelor of Geography training with good ethical qualities, love of teaching profession; ii) Meet the professional standards of teachers required by the Ministry of Education and Training of Vietnam; iii) Have self-study ability to improve professional qualifications and educational methods to meet the requirements of renovating general education in the future; iv) In addition, graduates can join in other fields relating to the training industry such as geography research, tourism,...

Thus, the programs are oriented to the training of geographers for the whole development in terms of quality, professional capacity, and specialized teaching capabilities to meet the requirements at present and future. General objectives are specified in output standards.

All 5 programs have an output standard design based on the output standards of the high school teacher training sector issued by the Ministry of Education and Training in 2012.

- Quality: Political and ethical qualities, civic responsibility; quality and professional manners. 
- Professional capacity: knowledge and skills related to objects, tasks, methodology geoscience research methods.

- Professional capacity: knowledge and skills in theoretical and methodological education in general and geographic education.

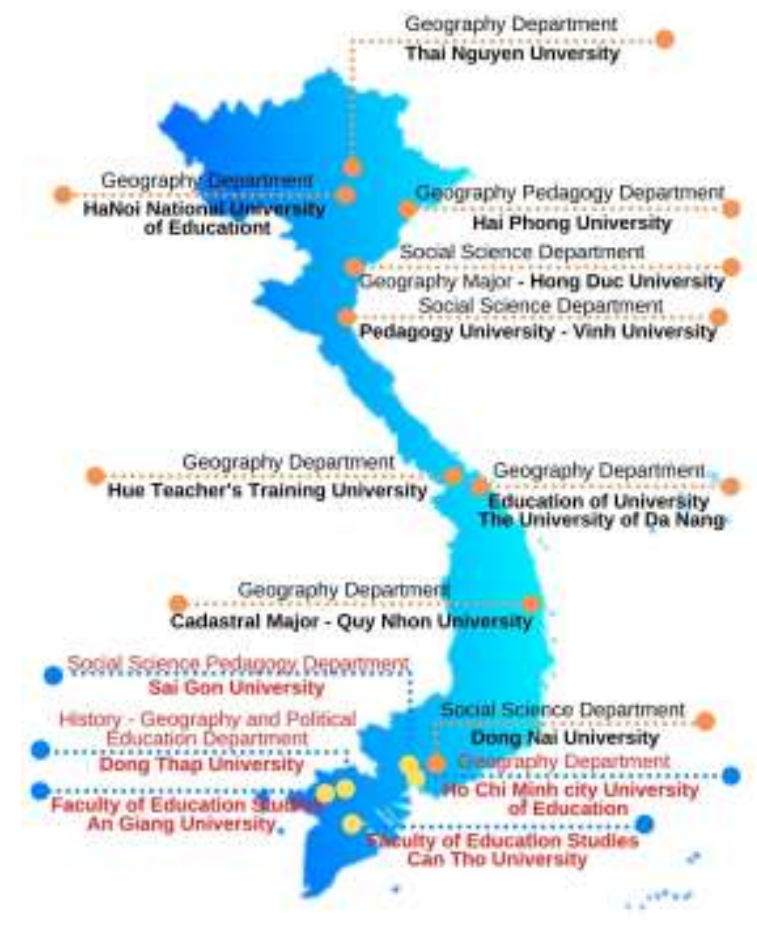

Figure 10. Training geography student-teachers institutions in Vietnam (by authors).

General competencies: Knowledge, basic skills for learning, research, and career development.

The framework curriculum of the institutions is presented in structures that are not exactly similar. However, the common characteristics between 5 programs are: The modules are divided into four groups: general knowledge, general foundation knowledge, content knowledge, internship knowledge, graduation thesis, alternative courses.

- General knowledge: includes subjects on political education, law, foreign languages, computing, physical education, security - defense, accounting more than $18 \%$ of the total credits. This is relatively consistent among all the universities in Vietnam.
- General foundation knowledge: includes modules related to educational science and pedagogy such as Introduction to the teaching career, general education, general education, psychology, scientific research methods. This type of knowledge accounts for the lowest proportion in the entire training program $(9 \%)$.

- Content knowledge: the modules are divided into 2 groups

+ Knowledge about geoscience: this type of knowledge ensures that students have complete and systematic knowledge and skills of geography. The subjects include Maps, GIS, Geology, General natural geography, general socio-economic geography, world geography, Vietnam geography, local geography, geoscience research methodology, etc. less than $50 \%$, accounting the largest proportion.

+ Specialized professional knowledge: includes subjects related to specialized teaching methods such as Geography theory and teaching methods, Development of geography curriculum, Assessment in teaching Geography, regularly trained Geography pedagogical profession, The application of IT to teaching Geography, Geography teaching method in high school. This type of knowledge accounts for $12 \%$ of the training program's capacity.

- Internship knowledge, graduation thesis, alternative courses: pedagogical internship, graduation thesis, graduation essay, alternative courses make up $11 \%$.

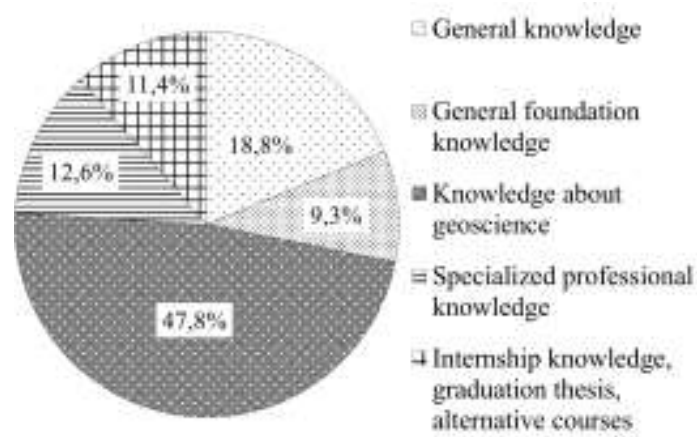

Figure 11. The average ratio of knowledge blocks in Geography Teacher Education curriculum of 5 universities in the Southeast and the Mekong. River Delta [10-[12]. 
Regarding the teaching plan, the system of subjects is evenly distributed in the 8 semesters of the 4-year training course. Normally, in semesters 1 and 2 students will study the modules of general knowledge group, general basis, and alternate some specialized modules. Specialized knowledge group is taught from semesters 1 to 7, focusing on semesters 3, 4, 5, 6 of knowledge cube. Cube of specialized career knowledge is taught starting in term 3 and some schools are period.

The geography student-teachers training program is maintained structurally stable but is also regularly updated in response to the current innovations of General geography education. The change of 2018 geography education program has affected the teacher training program in many aspects. Specifically, the designers update the program framework with new modules. These modules could directly respond to changes in general geography education. For example, in response to one of the key innovations of the 2018, the High School Geography Curriculum Development module helps geography teachers to develop a geography subject curriculum, adjusting to practical circumstances.

In addition, the theoretical teaching time is decreased to increase the time for practice and career internship. This change is aimed to give students more time for preparing enough competency requirements when they graduate. Therefore, training methods, assessment methods are renewed in the content of modules. In addition, the objectives of the modules support the output standards of the training program and are strictly controlled and operated.

In addition, several education universities opened the pedagogical training curriculum in History and Geography, responding to the training demand of teachers of History and Geography subject at junior high schools (the present curriculum is two independent subjects) [13]. It is designed and operated in the direction of the general teacher training curriculum, but the remarkable feature of this program is integration. Moreover, pedagogical organizations also design short-term training programs for teachers who are teaching History or Geography so that they can teach both fields.

3.3.3. Enhancing Geography Teachers Competencies

Enhancing Teacher Education Program (ETEP) is funded by the Vietnamese Ministry of Education and Training and World Bank. Its goal is to develop Education Universities and Educational management institutions to enhance the quality of teachers and education management through on-demand career development, meeting the needs of a fundamental and comprehensive renovation of education. The direct beneficiaries are teachers and school administrators [14].

Retraining Teacher training is done by using the "oil slick" approach (Figure 12) and blended learning method. Firstly, this program raises the education competencies for a small group of Geography lecturers at education universities. Secondly, it is help to develop professional skills for key geography teachers. Finally, the key Geography teachers popularize this task to all Geography teacher. $70 \%$ of the training time is online learning knowledge and the remaining $30 \%$ offline. There are 9 modules in a 3-year period (from 2019-2021). Geography teachers participate 5 compulsory modules include: Instructions for implementing 2018 General education curriculum; Using teaching methods, educating to develop learners' qualities and competencies; Examining and evaluating learners' qualities and competencies; Building teaching and education plans in the direction of developing learners' qualities and competencies; Applying information technology, using technological equipment in educating. The modules are closely connected with geography teaching at primary schools, secondary schools, and high schools [15].

\section{Conclusion}

In conclusion, this paper focuses on the differences between Geography Education curriculum 2018 and 2006. That is the changes of the curriculum's aim which leads to the 
adjustment in teaching process and assessment at high school. The improvements in the Geography Education Curriculum 2018 in comparison with the 2006 ones is an actual need for supplying the socio-economic requirements, i.e., the five core qualities and ten key competencies.

The changes of the 2018 curriculum also leads to the innovation of the training geographical pedagogical curriculum at the universities. The analysis of primary data collected in this paper demonstrates that there is a very close link between the Geography Education curriculum at high school and the geographical pedagogical curriculum at the universities. More importantly, curriculum at the universities needs to change not only to train the new teacher but also to retrain the teachers at high school. The primary data on the changes of curriculum at the universities such as: added new modules, renew modules, etc. assert the vital role of pedagogical university on education. It also proves that the rationality of those improvements or changes need to be done in the pedagogical university.

Therefore, further research should focus on specific improvements in the methods of training, the changes in assessment etc. to enhance the geography teachers' competences for implementing the 2018 curriculum at high school.

\section{References}

[1] B. M. Hung, General Education Curriculum 2018: Introduction, Presentation, https://slideplayer.com/slide/14736319/, 2019 (accessed on: March 6 ${ }^{\text {th }}, 2021$ ) (in Vietnamese).

[2] MOET, General Education Curriculum, Hanoi, 2018 (in Vietnamese).

[3] S. Bednarz, Geography Education Research in the Journal of Geography 1988-1997, International Research in Geographical and Environmental Education, Vol. 9, No. 2, 2000, pp. 128-40, https://doi.org/10.1080/10382040008667641.

[4] MOET, General Education Curriculum - Geography Curriculum, Hanoi, 2018b (in Vietnamese).

[5] N. V. Thinh, D. T. M. Duc, The Definition of Geography-specific Competencies in Learning and the Assessment of Pupils' Attained Competencies in the New National Curriculum,
The Proceeding of the $11^{\text {th }}$ National Geographic Conference, Hue: Thanh Nien, 2018, pp. 1044-1054 (in Vietnamese).

[6] MOET, General Education Curriculum-geography Curriculum, Hanoi, 2006 (in Vietnamese).

[7] MOET, Standards, Process of Editing, Editing Textbooks; Standards of Organization and Individual Reparing Science Books; Organization and Operation of the National Council of Science Book Assessment, 22 December 2017 (in Vietnamese).

[8] N. V. Thinh, H. V. Thang, Identifying Professional Competencies for Geography Teacher in Response to Vietnamese New General Education Curriculum, In The $1^{\text {st }}$ Internatonal Conference on Innovation in Learning Instruction and Teacher Education ILITE1, University of Education Publishing House, 2019, pp. 244-252.

[9] Ho Chi Minh City University of Education (HCMUE), Higher Education Curriculum Geography Teacher Education, Ho Chi Minh City, 2018 (in Vietnamese).

[10] Sai Gon University (SGU), Higher Education Curriculum-geography Teacher Education, Ho Chi Minh City, September $08^{\text {th }} 2020$ (in Vietnamese).

[11] Dong Thap University of Education (DThU), Higher Education Curriculum-geography Teacher Education, Dong Thap, 28 August 2018 (in Vietnamese).

[12] Can Tho University of Education (CTU), Higher Education Curriculum-geography Teacher Education, Can Tho, July 30 2019 (in Vietnamese).

[13] An Giang University of Education (AGU), Higher Education Curriculum-geography Teacher Education, An Giang, 2018 (in Vietnamese).

[14] Ho Chi Minh City University of Education (HCMUE), Higher Education Curriculum-history Geography Teacher Education, Ho Chi Minh City, September $24^{\text {th }} 2020$ (in Vietnamese).

[15] MOET, Enhancing Teacher Education ProgramETEP Instrucing about the Developing Universities of Education Program in Oder to Enhance Competence for Teachers and Educational Managers in General Education Institution, Hanoi, 2017 (in Vietnamese).

[16] MOET, Enhancing Teacher Education Program-ETEP Introducing Modules on the Implementation of the 2018 General Education Curriculum for Teachers in the Period of 2019-2021, Hanoi, 19 February, https://etep.moet.gov.vn/, 2020 (accessed on: March $\left.6^{\text {th }}, 2021\right)$ (in Vietnamese). 